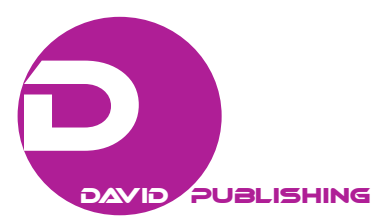

\title{
Four Rare and Unusual Dedications From Areas of Viminacium and Nais
}

\author{
Radmila Zotović \\ Institute of Archaeology, Belgrade, Serbia
}

\begin{abstract}
In the areas of Viminacium and Nais four rare and unusual votive dedications were identified. These are the dedications Deus Aeternus, Dii Angeli, Hero (Viminacium), and Atta (Naissus). The dedications Deus Aeternus and Dii Angeli may perhaps indicate Christianity, while the dedications Hero and Atta may indicate settlers of Greek origin. The dedication to goddess Atta could have been made by a freed man, since her cult was to an extent related to the cult of Heracles who, thanks to his loyal service to Omphale, where he was to repent his sins, was freed from slavery, and thus was also a protector of freed man. Main methodological approach in this paper is the analysis of cults as well as their backgrounds as conditions for their realisation. Until now for the territory of Serbia there was not corpus of analyzing cults. There is only corpus of grave and votive monuments for the territory of Serbia with very rare and sporadic comments of cult. So, the main topic of this article is analyzing of cults. It includes the main meaning of the cult, dateing of monuments and historical and archeological backgrounds of the cults. At the same time it was the main method in the analyzing of the mentioned votive monuments. By this method as the result appeared the dateing of the monuments and improvement of existing Greek settlers. At the same time there were the main research questions which should be ensolved. For ensolved the dateing of the monuments was used the system of analyzing syllabic formulae and for the improvement of existing Greek settlers the method of "healty mind" and connections of analogies. As a result the dateing of monuments of Deus Aeternus, Dii Angeli, and Hero was early 2-nd century, and for Atta from the beginning of 2-nd to the end of 3-rd century.
\end{abstract}

Keywords: Roman period, Viminacium, Naissus, votive monuments, cult of Deus Aeternus, Dii Angeli, Hero and Atta, early dateing of Christianity, improvement of existing Greek settlers

\section{Introduction}

In the areas of Viminacium and Naissus four votive monuments with rare, unusual dedications of highly intriguing meaning were identified. These are the votive monuments with dedications Deus Aeternus, Dii Angeli and Hero (cat. no. 1-3, Viminacium), and Atta (cat. no. 4, Naissus). It is nesessery to underline the importance of this thema, and it is not only in appearing the Christianity and Greek settlers on the territory of Viminacium and Nais, but appearing of early chistianity in the early 2 nd century and the reasons why the Greek settlers dedicated the monuments. In one reason it was concluded that they were very often separate from their beloved ones and in the second that they might be grateful for the freedom and the future better step in the

Radmila Zotović, Ph.D. of Classical Archaeology, Institute of Archaeology, Belgrade, Serbia.

Corespodence concerning this article should be addressed to Radmila Zotović, Institute of Archaeology, Knez Mihailova 35/IV, Belgrade 11000, Serbia. 
society. But, the main problems were missing of the literaturae and so very rare analogies. If there are missing, there was historical and archaeological background for this except for goddess Atta. Before that was important to discuss syllabic (onomastic) formulae to find out more about dedications and the reason why they did make. As a result it was found the date of monuments and reasons why they were made.

\section{Main Source for Researching}

The main source for researching was literaturae. Some of them had only description of the monuments (Вулић, 1905; 1941-1948; Petrović, 1979). Only in one case existed with the description of the monument and the comment (Mirković, 1986). It was about a Syrian deity Na'lim, but without deeper explanation about why this monument (Deus Aeternus) should be dedicated to this deity. After that was neccesery to compare the facts with the life of Christians (Hamman, 1998) and where was the most numerous number of Christians (Поповић, 1973).

The basic literature for the cults was the dictionaries (Замуровић, 1936; Срејовић \& Цермановић-Кузмановић, 1979), which were important for analogies of meanining of deitis atributes.

Also, it was neccesery to include the dictionary of Latin language (Богдановић \& Ристић, 1931) because of menntioning the meaning female deity in the word Deus.

\section{Main Directive for Researching}

The greatest problem was with the dedication Deus Aeternus, since it was only one in the territory of Serbia. The comment that it is the god Na'lim has not been enough clear (Mirković, 1986). There was not analogy for that, so the thinking about this problem was going into two direction: 1) There is no analogy for the dedication Na'lim; 2) There are the graves without the given goods for which is belived that they belong to Christians. So, the most probably is to be decided for Christians in these parts than for the beliving in the god Na'lim.

For other dedications have been used mithological dictionary and have been used analogies between gods and goddess to ensolve the problems.

\section{Four Rare and Unusual Dedications}

They should be looked at in order, the first intriguing thing is the dedication Deo Aeterno, or to the God eternal, immortal, or in the Nominative Singular Deus Aeternus (Figure 1). There is no other dedication like that in our parts, or in the territory of Bosnia and Herzegovina (Imamović, 1977).

It is believed that they were numerous in the territory of Dacia from 2nd and 3rd centuries (Mirković, 1986), and that they referred to different deities, but that they may first be connected to a Syrian deity Na'lim. It is possible to believe that the dedication is originated from the East, but judging by the nature of dedication it is most probable that Christian God is hidden behind this dedication, the only one, immortal and eternal. It is probable that the dedication was made in the early phase of converting to Christianity, judging by the name and gentilicium of the dedicant at the time of Emperor Hadrian, and thus an "old" form was used for the dedication, in this case a typical morphological shape of a square ara with the capital and base, separated from the body of the monument by emphasised mouldings. Christian dedications may also include the dedication Diis Angelis, i.e. in the Nominative Dii Angeli (Figure 2). For this dedication there were previous assumptions that it belongs to Judeo-Christian dedications, and opinions tend to take two different directions. One is that it belongs to the 
cult of the dead, and the other that it is of a more general meaning and cannot be subject to closer orientation. It is finally opinion that this dedication may be identified more closely as a dedication of a general meaning, since angels in Christianity are both escorts and guardians in this world. This dedication, which is a unique one in the territory of Serbia, may, judging by the dedicant's name, be dated into the period of Marcus Aurelius. If these two dedications taken into account, it would mean that it was as early as 2nd century that there was a Christian community in the territory of Viminacium.

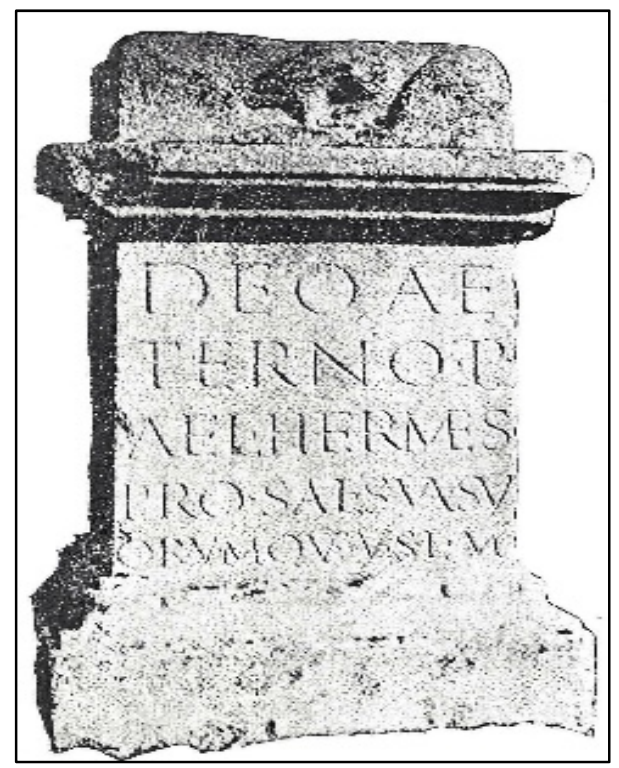

Figure 1. Votive Monument of Deus Aeternus.

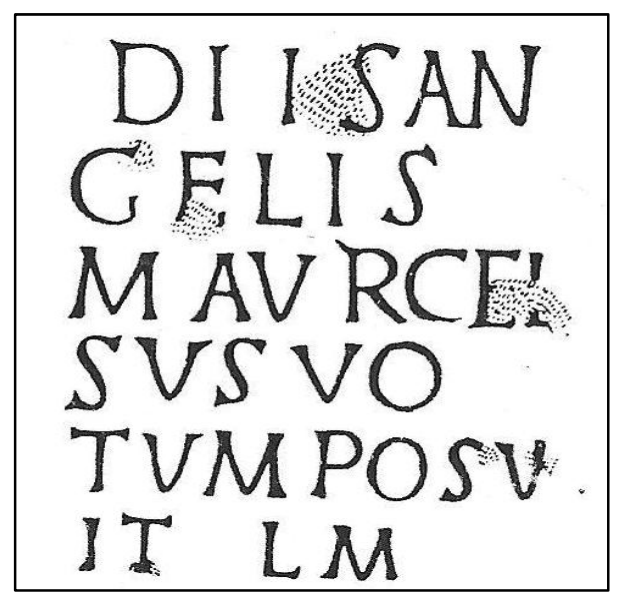

Figure 2. Inscription from Votive Monument of Dii Angeli.

The third dedication was made to Hero (Figure 3), priestess of the goddess Aphrodite (Срејовић \& Кузмановић-Цермановић, 1979). It is interesting that in this dedication she was deified, and that a corrupt form of the word Deus, god, which sometimes may mean a goddess as well, was used for the dedication (Богдановић \& Ристић, 1931). Hero was a beautiful priestess to the goddess Aphrodite with whom young hero Leander from the city of Abydos in Asia Minor fell in love. Since Hero lived and served in Sestos in Europe, young Leander had to swim across the Hellespont every night so that he could be held by the arms of his 
beloved (Замуровић, 1936; Срејовић \& Цермановић-Кузмановић, 1979). Love between the two young people ended in a tragedy. One night the tempest extinguished the torch that Hero lit every night, and in the morning the sea brought Leander's body to the shore instead to the arms of his beloved. In desperation Hero climbed the tower and jumped to her death. The dedicant for this dedication is a veteran of IV Flavie Antoniniane, Aurelius Gaius. According to the two-element onomastic formula it is possible to date this monument into the time of Marcus Aurelius. It is no wonder that the dedication was made by a veteran, a former soldier, since they were frequently separated from their beloved ones. It is possible that a Romanised Greek hides behind the name of this soldier, and that Hero in some parts of Greece and Asia Minor was celebrated as a deity. Her name appeared in this dedication in a vulgarised and incomplete name of Eroni, i.e. Ero.

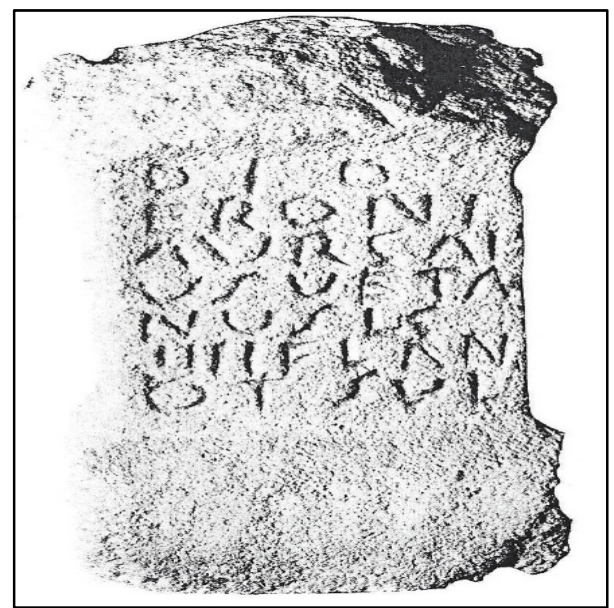

Figure 3. Votive Monument of hero.

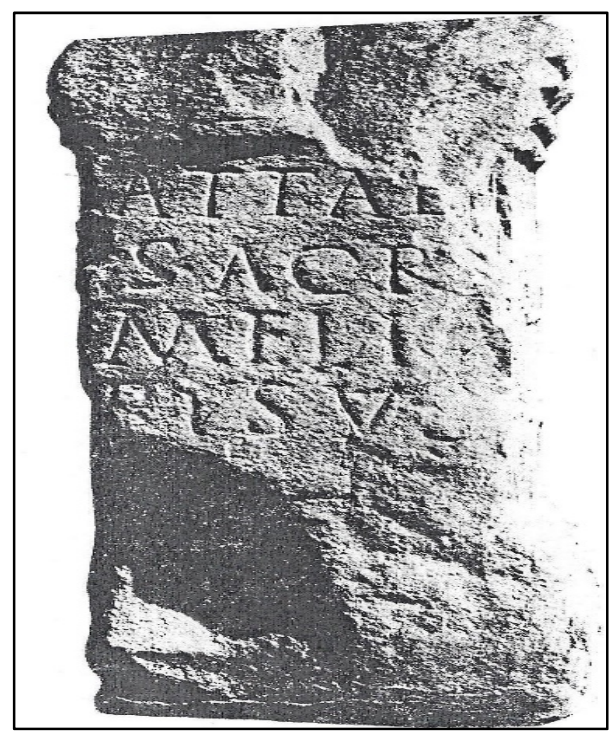

Figure 4. Votive Monument of Atta.

The fourth rare and unusual monument in these parts is a votive Ara to goddess Atta from the area of Naissus (Figure 4). Atta was a daughter of Zeus and Eris, an evil goddess that leads men to mindless acts and follows them around like an evil fate, driving them to sins, sometimes even ruin. At first Atta dwelled at 
Olympus, but Zeus, after she talked him into making a rash statement about Heracles' fate, threw her down to earth. From that time on she walks silently above the heads of men, provoking them to commit all kinds of mindless and unfortunate acts (Замуровић, 1936; Срејовић \& Цермановић-Кузмановић, 1979). It is no wonder that she is like that since she is daughter of Eris, and Eris herself is a goddess of misfortune and discord. The dedicant for this dedication from Nais is mentioned in a single element formula, so it is possible to consider that he may have been a freed man, even more so since the cult of Atta was linked to the cult of Heracles who, having been a slave in service of Omphala in order to repent his sins, was also a protector of freed men. It is possible that a freed man had this dedication made to Atta in order to ask for blessing for his evil fate and for further steps to be made in his life. The monument may be dated into a broader chronological period from 2 nd century to the end of 3 rd century.

\section{Historical and Archaeological Background of the Cults}

There are no archaeological and more reliable data on the presence of Christianity in territory of modern Serbia in the period of Roman rule prior to 4th century. A funerary monument from Kolovrat near Prijepolje (Зотовић, 1995) is believed to be the first more reliable evidence of Christians in these parts, since there is a cross inscribed in it. Earlier evidence of Christianity is considered to be graves without grave goods, since Christians paid much attention to humility and moderation during life, and thus also on their way to eternal life. As for historical evidence for Christianity in the territory of modern Serbia, there is also none, except perhaps a referral to the general directions of Christianity developing in Roman provinces (Hamman, 1998). Thus Christians had secret gatherings, most often in inns whose names contained the word "red", and it is also known that Christian guidelines prohibited Christians from working in municipal services and magistratures. According to biographies of the saints (Popović, 1973), most converts came from the ranks of the military.

As for the dedication to beautiful Hero, there are no data about a widespread cult in Roman provinces, especially not in the western ones, but it is known that this myth made part of artistic presentations rather early on. Musaeus wrote about the lovers in a short epic poem "Hero and Leander" in 5th to 6th centuries, believed to have stemmed from a Hellenistic legend, probably from as early as 3rd century CE. It is also known that they were presented in the Abydos currency, as well as in Pompeian frescoes (Срејовић \& Цермановић-Кузмановић, 1979).

The cult of Atta was known, but it was obviously not widespread either in the western provinces of the Empire or in the provinces of the modern day Balkans.

\section{Conclusion}

The cults, or votive monuments believed to be Christian, may be dated into the first half of 2 nd century, just like the votive monument dedicated to Hero. It is only the monument dedicated to Atta that may be dated into a broader chronological period, from 2nd century till the end of 3rd century. Dedications to Hero and Atta are indicative of the presence of Romanised Greek settlers.

\section{References}

Вулић, Н. (1905).

Вулић, Н. (1941-1948). Антички споменици наше земље. Споменик Српске академије наука и уметности XCVIII, 1-256.

Срејовић, Д., \& Цермановић-Кузмановић, А. (1979). Речник грчке и римске митологије. Београд Српска књижевна задруга. 
Hamman, A. G. (1998). Rim i prvi hrišćani. Beograd: bukur book.

Imamović, E. (1977). Antički kultni i votivni spomenici na području Bosne i Hercegovine. Sarajevo Veselin Masleša.

Mirković, M. (1986). Inscriptiones de la Mésie Supérieure, vol II, Viminacium et Margum. Belgrade Faculte de Philosophie.

Petrović, P. (1979). Inscriptiones de la Mésie Supérieure, vol IV, Naissus-Remesiana-Horeum Margi. Belgrade Faculte de Philosophie.

Popović, J. (1973). Žitija svetih za april. Beograd: Srpska pravoslavna crkva.

Богдановић, Б., \& Ристић, С. (1931). Латинско-српски речник. Београд Издање Књижарнице Рајковића и Ћуковића. Замуровић, А. (1936). Митолошки речник. Београд Геца Кон.

Зотовић, Р. (1995). Римски надгробни споменици источног дела римске провинције Далмације. Ужице Кадињача. 